Review

\title{
Evolving Evidence of the Efficacy and Safety of nab-Paclitaxel in the Treatment of Cancers with Squamous Histologies
}

\author{
Herbert H. Loong ${ }^{1,2}$, Alvita C.Y. Chan², Ashley C.Y. Wong² \\ 1. Department of Clinical Oncology, State Key Laboratory in Oncology in South China, Hong Kong Cancer Institute, The Chinese University of Hong Kong, \\ 30-32 Ngan Shing Street, Shatin, NT, Hong Kong SAR \\ 2. Department of Clinical Oncology, Prince of Wales Hospital, 30-32 Ngan Shing Street, Shatin, NT, Hong Kong SAR \\ $\square$ Corresponding author: Herbert H. Loong, MBBS, MRCP, FHKCP, FHKAM (Medicine), Assistant Professor (Clinical), Department of Clinical Oncology, State \\ Key Laboratory in Oncology in South China, The Chinese University of Hong Kong, Prince of Wales Hospital, 30-32 Ngan Shing Street, Shatin, NT, Hong Kong \\ SAR. Email: h_loong@clo.cuhk.edu.hk, Tel: +852 26322166 \\ (1) Ivyspring International Publisher. Reproduction is permitted for personal, noncommercial use, provided that the article is in whole, unmodified, and properly cited. See \\ http://ivyspring.com/terms for terms and conditions.
}

Received: 2015.06.18; Accepted: 2015.10.18; Published: 2016.01.08

\begin{abstract}
Taxanes, such as paclitaxel and docetaxel, are well-established cytotoxic chemotherapeutics used in the treatment of a variety of cancers, including those of squamous histology. In their formulation, both agents require solvents, which have been associated with hypersensitivity reactions, peripheral neuropathy, hepatic toxicities, and impaired drug delivery. nab-Paclitaxel is a novel, albumin-bound form of paclitaxel with improved tolerability, bioavailability, and efficacy compared with solvent-based paclitaxel. Currently, nab-paclitaxel is approved for the treatment of metastatic breast cancer, locally advanced/metastatic non-small cell lung cancer (NSCLC), and metastatic pancreatic cancer. Clinical studies suggest that nab-paclitaxel may be particularly effective in cancers with squamous histology, including NSCLC. This article reviews the emerging evidence supporting nab-paclitaxel as an effective agent in the treatment of malignancies of squamous histology.
\end{abstract}

Key words: nab-paclitaxel, squamous cell carcinoma, non-small cell lung cancer (NSCLC), head/neck cancer, nasopharyngeal carcinoma, esophageal cancer

\section{Introduction}

Cytotoxic chemotherapy is an essential component of cancer treatment, and taxanes are recommended agents for numerous cancers with squamous cell carcinoma (SCC) [1-4]. Paclitaxel and its semisynthetic analogue docetaxel are taxanes that act as microtubule stabilizers to inhibit cell division and, ultimately, lead to cell death [5-7]. Despite their considerable efficacy, paclitaxel and docetaxel are limited by their formulation requirements. Both agents are extremely hydrophobic and require the use of solvents to enhance solubility and create an injectable solution $[8,9]$. Paclitaxel is formulated in the castor oil derivative Kolliphor EL (originally Cremophor EL), and docetaxel is formulated using polysorbate 80 . These solvents are associated with impaired drug delivery and toxicities such as peripheral neuropathy and hypersensitivity reactions requiring the use of steroid pretreatment [8-12].

nab-Paclitaxel is an albumin-bound form of paclitaxel that was designed to overcome the limitations associated with solvent-based taxanes [13]. The use of $130-\mathrm{nm}$ albumin particles as carriers in $n a b$-paclitaxel's formulation improves tolerability by eliminating the need for chemical solvents. The albumin formulation also improves drug bioavailability, as nab-paclitaxel has demonstrated increased paclitaxel tumor delivery in preclinical models compared with solvent-based paclitaxel [14]. In a population pharmacokinetic/pharmacodynamic study, nab-paclitaxel also demonstrated faster and deeper 
tissue penetration and slower elimination than its solvent-based counterpart in patients with advanced solid tumors [15]. It is hypothesized that nab-paclitaxel utilizes receptor-mediated albumin transcytosis to internalize paclitaxel in the tumor interstitium [16, 14, 17]. Other evidence suggests that passive diffusion due to enhanced vascular permeability may play a role [18].

Squamous cell carcinomas can be difficult to treat, and patients with this particular histology comprise a large unmet need, as outcomes may be worse for those with SCC compared with other histologies $[19,20]$. In addition, some agents may not be indicated for treating SCC due to efficacy or safety issues [21, 22]. Recently, nab-paclitaxel has demonstrated activity in several SCC tumor types, such as non-small cell lung cancer (NSCLC), cervical cancer, and head and neck cancers, including cancer of the oropharynx, esophageal cancer, and nasopharyngeal cancer (NPC). Here we provide an overview of recent studies of nab-paclitaxel in SCC.

\section{Potential mechanism of tumor delivery of $n a b$-paclitaxel in cancers}

nab-Paclitaxel has been postulated to enter tumors through interaction with secreted protein acidic and rich in cysteine (SPARC), also known as osteonectin or BM-40 [23, 24]. SPARC is an albumin-binding protein with similar affinity to that of the albumin receptor (gp60) itself, and high SPARC expression may possibly be associated with tumor progression in several cancers [17, 24]. SPARC expression has been associated with poor outcomes in NSCLC, head and neck cancer, breast cancer, and early stage pancreatic cancer [25-29].

Data regarding SPARC expression and nab-paclitaxel activity remain limited, particularly in the SCC setting. SPARC expression was associated with a higher response rate in a study of 60 patients with head and neck cancer treated with nab-paclitaxel
[23]. Patients with SPARC positivity $(\mathrm{n}=12)$ demonstrated an overall response rate (ORR) of $83 \%$ compared with $25 \%$ in patients who were SPARC negative $(\mathrm{n}=4)$. A phase I/II study assessed SPARC expression in patients with advanced NPC treated with nab-paclitaxel plus cisplatin [30]. SPARC was assessed in 62 cases, and patients with both high stromal and tumoral SPARC expression demonstrated an ORR of $82 \%$ compared with $20 \%$ in patients with low stromal and high tumoral SPARC expression. In addition, patients with both low stromal and tumoral SPARC expression demonstrated an ORR of $80 \%$, and patients with high stromal and low tumoral SPARC expression had an ORR of $60 \%$. As head and neck cancers are predominantly of SCC histology, these studies provide additional clues regarding outcomes in patients with SCC histology treated with nab-paclitaxel. SPARC expression and nab-paclitaxel activity were also evaluated in a single-arm phase II trial of patients with advanced NSCLC who were ineligible for bevacizumab treatment (due to bleeding risk, bevacizumab is contraindicated in patients with SCC or hemoptysis) [31]. The study enrolled 63 patients, the majority of whom (76\%) had SCC. No association was observed between tumoral or stromal SPARC expression and response to treatment with nab-paclitaxel plus carboplatin. Although the results are intriguing, these studies were performed in a limited patient population. In one of the largest studies assessing SPARC, a phase III trial of patients with pancreatic cancer, SPARC expression was neither predictive nor prognostic of overall survival (OS) [32].

\section{Current clinical data for $n a b$-paclitaxel in malignancies of SCC histology}

Emerging data from recent clinical trials suggest that nab-paclitaxel may be particularly effective and well tolerated in patients with cancers of SCC histology (Tables 1 and 2).

Table 1. Select efficacy outcomes of trials of nab-paclitaxel regimens in squamous cell carcinoma.

\begin{tabular}{|c|c|c|c|c|}
\hline No. of SCC Patients & Regimen & OS, Median mo & PFS, Median mo & Reference \\
\hline \multicolumn{5}{|l|}{ NSCLC } \\
\hline 63 & $n a b-\mathrm{P} 260 \mathrm{mg} / \mathrm{m}^{2, \mathrm{a}}+$ Carbo AUC $6 \mathrm{q} 3 \mathrm{w}$ & 9.7 & 5.0 & Bertino et al [31] \\
\hline 40 & $n a b-\mathrm{P} 125 \mathrm{mg} / \mathrm{m}^{2} \mathrm{qw} 2 / 3+$ cisplatin $75 \mathrm{mg} / \mathrm{m}^{2}$ or Carbo AUC $5 \mathrm{q} 3 \mathrm{w}$ & NR & $5^{\mathrm{b}}$ & Fang et al [33] \\
\hline 43 & $n a b-\mathrm{P} 260 \mathrm{mg} / \mathrm{m}^{2} \mathrm{q} 3 \mathrm{w}$ & 11 & NR & Green et al [34] \\
\hline 229 & $n a b-\mathrm{P} 100 \mathrm{mg} / \mathrm{m}^{2} \mathrm{qw}+$ Carbo AUC $6 \mathrm{q} 3 \mathrm{w}$ & 10.7 & 5.6 & Socinski et al [36] \\
\hline 221 & $\mathrm{sb}-\mathrm{P} 200 \mathrm{mg} / \mathrm{m}^{2} \mathrm{q} 3 \mathrm{w}+$ Carbo AUC $6 \mathrm{q} 3 \mathrm{w}$ & 9.5 & 5.7 & \\
\hline 60 & $n a b-\mathrm{P} 135 \mathrm{mg} / \mathrm{m}^{2} \mathrm{qw} 2 / 3$ + Carbo AUC $5 \mathrm{q} 3 \mathrm{w}$ & $11.9^{c}$ & 5.7 & Yang et al [38] \\
\hline 64 & Gem $1250 \mathrm{mg} / \mathrm{m}^{2} \mathrm{qw} 2 / 3+$ Carbo AUC $5 \mathrm{q} 3 \mathrm{w}$ & 14.4 & 4.8 & \\
\hline \multicolumn{5}{|l|}{ Head and Neck } \\
\hline 17 & $\begin{array}{l}n a b-\mathrm{P} 75-100 \mathrm{mg} / \mathrm{m}^{2} \mathrm{qw} 2 / 3+\text { Cis } 75-100 \mathrm{mg} / \mathrm{m}^{2} \mathrm{q} 3 \mathrm{w}+ \\
5-\mathrm{FU} 1000 \mathrm{mg} / \mathrm{m}^{2} / \mathrm{d} \times 96 \mathrm{~h} \mathrm{q} 3 \mathrm{w} \text {, followed by CRT }\end{array}$ & Not reached & Not reached & Loong et al [40] \\
\hline 30 & $\begin{array}{l}n a b-\mathrm{P} 100 \mathrm{mg} / \mathrm{m}^{2} \mathrm{qw}+\text { Cetux } 250 \mathrm{mg} / \mathrm{m}^{2, \mathrm{~d}} \mathrm{qw}+\mathrm{Cis} 75 \mathrm{mg} / \mathrm{m}^{2} \mathrm{q} 3 \mathrm{w}+5-\mathrm{FU} 750 \\
\mathrm{mg} / \mathrm{m}^{2} / \mathrm{d} \times \text { days } 1-3 \mathrm{q} 3 \mathrm{w}, \text { followed by CRT }\end{array}$ & NR & NR & Adkins et al [41] \\
\hline 11 & Cetux $400 \mathrm{mg} / \mathrm{m}^{2}$ week 1 followed by Cetux $250 \mathrm{mg} / \mathrm{m}^{2} \mathrm{qw}+$ & NR & NR & Nedzi et al [42] \\
\hline
\end{tabular}




\begin{tabular}{|c|c|c|c|c|}
\hline \multirow{2}{*}{\multicolumn{5}{|c|}{ Cis $20 \mathrm{mg} / \mathrm{m}^{2} \mathrm{qw}+n a b-\mathrm{P} 25 \mathrm{mg} / \mathrm{m}^{2, e} \mathrm{qw}$ with IMRT }} \\
\hline & & & & \\
\hline 33 & nab-P $250 \mathrm{mg} / \mathrm{m}^{2} \mathrm{q} 4 \mathrm{w}+$ Cis $75 \mathrm{mg} / \mathrm{m}^{2} \mathrm{q} 3 \mathrm{w}$ & 15.5 & 6.2 & Shi et al [44] \\
\hline 35 & nab-P $100 \mathrm{mg} / \mathrm{m}^{2}$ days $1,8,22,29+$ Cis $75 \mathrm{mg} / \mathrm{m}^{2}$ days 1,22 & NR & NR & Fan et al [43] \\
\hline \multicolumn{5}{|c|}{ Nasopharyngeal } \\
\hline 23 & $n a b-\mathrm{P} 260 \mathrm{mg} / \mathrm{m}^{2} \mathrm{q} 3 \mathrm{w}+$ Cis $75 \mathrm{mg} / \mathrm{m}^{2} \mathrm{q} 3 \mathrm{w}$ & NR & 7 & Zhang et al [28] \\
\hline 22 & nab-P $140 \mathrm{mg} / \mathrm{m}^{2}$ days $1,8 \mathrm{q} 3 \mathrm{w}+\mathrm{Cis} 75 \mathrm{mg} / \mathrm{m}^{2} \mathrm{q} 3 \mathrm{w}$ & & 6 & \\
\hline 24 & $n a b-\mathrm{P} 100 \mathrm{mg} / \mathrm{m}^{2} \mathrm{qw}+$ Cis $75 \mathrm{mg} / \mathrm{m}^{2} \mathrm{q} 3 \mathrm{w}$ & & 9 & \\
\hline \multicolumn{5}{|c|}{ 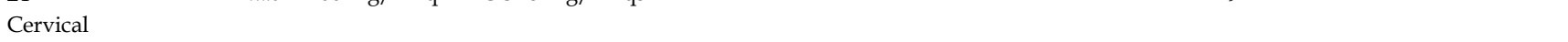 } \\
\hline 37 & nab-P $125 \mathrm{mg} / \mathrm{m}^{2} \mathrm{gw} 3 / 4$ & 9.4 & 5.0 & Alberts et al [47] \\
\hline
\end{tabular}

Abbreviations: 5-FU, 5-fluorouracil; AUC, area under the curve; Carbo, carboplatin; Cetux, cetuximab; Cis, cisplatin; CRT, chemoradiation; Gem, gemcitabine; IMRT, intensity-modulated radiation therapy; nab-P, nab-paclitaxel; NR, not reported; NSCLC, non-small cell lung cancer; OS, overall survival; PFS, progression-free survival; q3w, every 3 weeks; q4w, every 4 weeks; qw, weekly; qw 2/3, the first 2 of 3 weeks; qw 3/4, the first 3 of 4 weeks; sb-P, solvent-based paclitaxel; SCC, squamous cell carcinoma.

a Reduced from $300 \mathrm{mg} / \mathrm{m}^{2}$ due to excess neuropathy.

b $67 \%$ of patients had SCC.

c Results not final. At the time of report, $62 \%$ of survival events had been recorded

d Loading dose of Cetux $400 \mathrm{mg} / \mathrm{m}^{2}$ given on day 1.

e $n a b$-P dose reduced to $20 \mathrm{mg} / \mathrm{m}^{2}$ after treatment of first 6 patients.

Table 2. Select safety outcomes of trials of nab-paclitaxel regimens in squamous cell carcinoma.

\begin{tabular}{|c|c|c|c|}
\hline $\begin{array}{l}\text { No. of SCC } \\
\text { Patients }\end{array}$ & Regimen & Key Grade $\geq 3$ Adverse Events (\%) & Reference \\
\hline \multicolumn{4}{|l|}{ NSCLC } \\
\hline $63^{\mathrm{a}}$ & $n a b-\mathrm{P} 260 \mathrm{mg} / \mathrm{m}^{2, \mathrm{~b}}+$ Carbo AUC $6 \mathrm{q} 3 \mathrm{w}$ & $\begin{array}{l}\text { Neutropenia (19), anemia (11), thrombocytopenia (11), } \\
\text { neuropathy (30) }\end{array}$ & Bertino et al [31] \\
\hline 40 & $\begin{array}{l}n a b-\mathrm{P} 125 \mathrm{mg} / \mathrm{m}^{2} \mathrm{qw} 2 / 3+\text { cisplatin } 75 \mathrm{mg} / \mathrm{m}^{2} \text { or } \\
\text { Carbo AUC } 5 \mathrm{q} 3 \mathrm{w}\end{array}$ & Thrombocytopenia (10), neuropathy (7.5c) & Fang et al [33] \\
\hline $43^{\mathrm{d}}$ & $n a b-\mathrm{P} 260 \mathrm{mg} / \mathrm{m}^{2} \mathrm{q} 3 \mathrm{w}$ & Neutropenia (9), neuropathy (5) & Green et al [34] \\
\hline $222 \mathrm{e}$ & $n a b-\mathrm{P} 100 \mathrm{mg} / \mathrm{m}^{2} \mathrm{qw}+$ Carbo AUC $6 \mathrm{q} 3 \mathrm{w}$ & $\begin{array}{l}\text { For nab-P regimen: neutropenia (43), anemia (26), throm- } \\
\text { bocytopenia ( } 22), \text { neuropathy ( } 3 \text { ) }\end{array}$ & Socinski et al [36] \\
\hline $214^{\mathrm{e}}$ & sb-P $200 \mathrm{mg} / \mathrm{m}^{2} \mathrm{q} 3 \mathrm{w}+$ Carbo AUC $6 \mathrm{q} 3 \mathrm{w}$ & $\begin{array}{l}\text { For sb-P regimen: neutropenia (51), anemia (4), thrombo- } \\
\text { cytopenia ( } 7) \text {, neuropathy (12) }\end{array}$ & \\
\hline 59 & $n a b-\mathrm{P} 135 \mathrm{mg} / \mathrm{m}^{2} \mathrm{qw}$ 2/3 + Carbo AUC $5 \mathrm{q} 3 \mathrm{w}$ & $\begin{array}{l}\text { For nab-P regimen: neutropenia (70), anemia (22), } \\
\text { thrombocytopenia ( } 35)\end{array}$ & Yang et al [38] \\
\hline 65 & Gem 1250 mg/m² qw 2/3 + Carbo AUC 5 q3w & $\begin{array}{l}\text { For Gem regimen: neutropenia (42.2), anemia (27), } \\
\text { thrombocytopenia ( } 44 \text { ) }\end{array}$ & \\
\hline \multicolumn{4}{|c|}{ Head and Neck } \\
\hline 17 & $\begin{array}{l}n a b-\mathrm{P} 75-100 \mathrm{mg} / \mathrm{m}^{2} \mathrm{qw} 2 / 3+\text { Cis } 75-100 \mathrm{mg} / \mathrm{m}^{2} \mathrm{q} 3 \mathrm{w}+ \\
5 \text {-FU } 1000 \mathrm{mg} / \mathrm{m}^{2} / \mathrm{d} \times 96 \mathrm{~h} \mathrm{q} 3 \mathrm{w} \text {, followed by CRT }\end{array}$ & Neutropenia (23), thrombocytopenia (6) & Loong et al [40] \\
\hline 30 & $\begin{array}{l}n a b-\mathrm{P} 100 \mathrm{mg} / \mathrm{m}^{2} \mathrm{qw}+\text { Cetux } 250 \mathrm{mg} / \mathrm{m}^{2} \mathrm{qw}+\text { Cis } 75 \mathrm{mg} / \mathrm{m}^{2} \\
\mathrm{q} 3 \mathrm{w}+5 \text {-FU } 750 \mathrm{mg} / \mathrm{m}^{2} / \mathrm{d} \times 72 \mathrm{~h} \mathrm{q} 3 \mathrm{w}, \text { followed by CRT }\end{array}$ & Neutropenia (20), anemia (3), thrombocytopenia (3) & Adkins et al [41] \\
\hline $10^{f}$ & $\begin{array}{l}\text { Cetux } 400 \mathrm{mg} / \mathrm{m}^{2} \text { followed by Cetux } 250 \mathrm{mg} / \mathrm{m}^{2} \mathrm{qw}+ \\
\text { Cis } 20 \mathrm{mg} / \mathrm{m}^{2} \mathrm{qw}+\text { nab-P } 25 \mathrm{mg} / \mathrm{m}^{2} \mathrm{qw} \text { with IMRT }\end{array}$ & Lymphopenia (11) & Nedzi et al [42] \\
\hline \multicolumn{4}{|l|}{ Esophageal } \\
\hline 33 & $n a b-\mathrm{P} 250 \mathrm{mg} / \mathrm{m}^{2} \mathrm{q} 4 \mathrm{w}+\mathrm{C}$ is $75 \mathrm{mg} / \mathrm{m}^{2} \mathrm{q} 2 \mathrm{w}$ & Neutropenia (3), neuropathy (3) & Shi et al [44] \\
\hline 35 & $n a b-\mathrm{P} 100 \mathrm{mg} / \mathrm{m}^{2} \mathrm{q} 3 \mathrm{w}+\mathrm{C}$ is $75 \mathrm{mg} / \mathrm{m}^{2} \mathrm{q} 3 \mathrm{w}$ & Neutropenia (11), anemia (9), thrombocytopenia (6) & Fan et al[43] \\
\hline \multicolumn{4}{|c|}{ Nasopharyngeal } \\
\hline 23 & $n a b-\mathrm{P} 260 \mathrm{mg} / \mathrm{m}^{2} \mathrm{q} 3 \mathrm{w}+\mathrm{C}$ is $75 \mathrm{mg} / \mathrm{m}^{2} \mathrm{q} 3 \mathrm{w}$ & For nab-P 260 regimen: neutropenia (65), anemia (13) & Zhang et al [28] \\
\hline 22 & $n a b-\mathrm{P} 140 \mathrm{mg} / \mathrm{m}^{2} \mathrm{qw} 2 / 3+$ Cis $75 \mathrm{mg} / \mathrm{m}^{2} \mathrm{q} 3 \mathrm{w}$ & For nab-P 140 regimen: neutropenia (67), anemia (5) & \\
\hline 24 & $n a b-\mathrm{P} 100 \mathrm{mg} / \mathrm{m}^{2} \mathrm{qw}+$ Cis $75 \mathrm{mg} / \mathrm{m}^{2} \mathrm{q} 3 \mathrm{w}$ & For nab-P 100 regimen: neutropenia (61), anemia (9) & \\
\hline \multicolumn{4}{|l|}{ Cervical } \\
\hline 35 & $n a b-\mathrm{P} 125 \mathrm{mg} / \mathrm{m}^{2} \mathrm{qw} 3 / 4$ & Neutropenia (9), anemia (11), thrombocytopenia (3) & Alberts et al [47] \\
\hline \multicolumn{4}{|c|}{$\begin{array}{l}\text { Abbreviations: 5-FU, 5-fluorouracil; AUC, area under the curve; Carbo, carboplatin; Cetux, cetuximab; Cis, cisplatin; CRT, chemoradiation; Gem, gemcitabine; IMRT, inten- } \\
\text { sity-modulated radiation therapy; nab-P, nab-paclitaxel; NR, not reported; NSCLC, non-small cell lung cancer; q2w, every } 2 \text { weeks; q3w, every } 3 \text { weeks; q4w, every } 4 \text { weeks; } \\
\text { qw, weekly; qw 2/3, the first } 2 \text { of } 3 \text { weeks; sb-P, solvent-based paclitaxel; SCC, squamous cell carcinoma. }\end{array}$} \\
\hline \multicolumn{4}{|c|}{ a Included patients ineligible for bevacizumab; 76\% had SCC. } \\
\hline \multicolumn{4}{|c|}{ b Reduced from 300 mg/m² due to excess neuropathy. } \\
\hline \multicolumn{4}{|c|}{ c Reported as neurotoxicity. } \\
\hline \multicolumn{4}{|c|}{ d $67 \%$ of patients had SCC. } \\
\hline e For sensory & athy, $\mathrm{n}=226$ in the $n a b-\mathrm{P}+$ Carbo arm and $\mathrm{r}$ & & \\
\hline
\end{tabular}

\section{nab-Paclitaxel in NSCLC of SCC histology}

Patients with NSCLC of SCC histology may be at risk for worse outcomes than patients with other histologies [19]. Generally, platinum doublets are the preferred first-line treatment for this patient popula- tion, and treatment choice is further restricted because some agents recommended for the treatment of advanced NSCLC are not indicated for SCC histology $[22,21,20]$. For example, pemetrexed and bevacizumab are not indicated in SCC due to a lack of efficacy and an increased risk of bleeding events, respec- 
tively [21, 22]. nab-Paclitaxel plus carboplatin is approved for treatment of NSCLC of any histology, and evidence suggests that the regimen may be particularly effective in patients with SCC histology [13].

Several early studies of nab-paclitaxel provided some evidence of its activity in patients with SCC NSCLC [31, 33, 34]. One of these studies, mentioned previously, enrolled 63 patients with advanced NSCLC who were ineligible for bevacizumab therapy (48 patients had SCC) [31]. Patients in this study received nab-paclitaxel plus carboplatin. This treatment regimen resulted in a $38 \%$ ORR, with $32 \%$ of patients experiencing stable disease and 16\% experiencing progressive disease. The median progression-free survival (PFS) and OS were 5.0 and 9.7 months, respectively. The most common grade $\geq 3$ toxicities included hematologic toxicities, sensory neuropathy, and fatigue. Another study evaluated the safety and efficacy of nab-paclitaxel in combination with a platinum agent in stage III/IV SCC NSCLC [33]. Chemotherapy-naive patients $(\mathrm{N}=40)$ received nab-paclitaxel and either cisplatin or carboplatin. The ORR was $63 \%$, the disease control rate was $93 \%$, and $30 \%$ of patients experienced stable disease. Patients receiving nab-paclitaxel combined with cisplatin vs carboplatin achieved an ORR of $74 \%$ vs $52 \%$. Adverse events were not reported separately for the cisplatin and carboplatin arms, but grade $\geq 3$ toxicities included leukocytopenia, thrombocytopenia, baldness, and nausea/vomiting. Finally, a phase II study enrolled 43 patients with advanced NSCLC, and most (67\%) had SCC; all patients were treated with single-agent nab-paclitaxel [34]. Overall, 7 patients had a confirmed overall response, 5 of whom had SCC; grade $\geq 3$ toxicities occurred in $21 \%$ of patients.

More robust evidence of the activity of nab-paclitaxel in SCC NSCLC came from a recent multicenter phase III registrational trial, in which more than 1000 chemotherapy-naive patients with advanced NSCLC received either weekly nab-paclitaxel plus carboplatin or solvent-based paclitaxel plus carboplatin [35]. In the intent-to-treat population, treatment with nab-paclitaxel plus carboplatin significantly improved the primary endpoint (ORR) compared with the solvent-based regimen (33 vs. $25 \%$; $95 \% \mathrm{CI}, 1.082-1.593 ; P=0.005)$, with a trend toward increased OS and PFS. In a subanalysis of patients with SCC $(\mathrm{n}=450)$, nab-paclitaxel plus carboplatin resulted in a significantly better ORR compared with solvent-based paclitaxel plus carboplatin $(41 \%$ vs. $24 \%$; response rate ratio 1.680 ; 95\% CI, 1.27-2.22; $P<0.001$ ) [36]. Similar to the intent-to-treat population, an approximately 1-month longer median OS was noted for patients with SCC in the nab-paclitaxel and carboplatin arm compared with those treated with solvent-based paclitaxel and carboplatin, but this difference was not significant (10.7 vs. 9.5 months; hazard ratio [HR] 0.89; $95 \% \mathrm{CI}$, $0.72-1.10 ; P=0.28$ ). Safety was similar regardless of histology. In a retrospective analysis of the same phase III trial, patients with SCC treated with nab-paclitaxel plus carboplatin beyond 4 cycles had a median PFS and OS from time of randomization of 6.8 and 13.8 months, respectively, with no new safety signals compared with the intent-to-treat population [37]. The ABOUND.sqm study has been initiated to further examine nab-paclitaxel for the treatment of SCC NSCLC in the maintenance setting (NCT02027428).

A randomized phase II trial recently compared the efficacy and safety of first-line nab-paclitaxel plus carboplatin versus gemcitabine plus carboplatin in more than 120 patients with advanced SCC of the lung [38]. ORR, the study's primary endpoint, was $46 \%$ and $30 \%$ for nab-paclitaxel plus carboplatin versus gemcitabine plus carboplatin, respectively $(P=0.085)$. There was no significant difference between the treatment arms with respect to median PFS and OS. However, median PFS improved approximately $19 \%$ with nab-paclitaxel plus carboplatin treatment (5.7 vs. 4.8 months, respectively; HR, 0.907; 95\% CI, 0.588-1.399; $P=0.657$ ). Treatment with nab-paclitaxel plus carboplatin was associated with a higher incidence of neutropenia and leukocytopenia compared with gemcitabine plus carboplatin, but no other significant differences in grade $\geq 3$ toxicities were noted. These safety results are consistent with the previous report from the phase III trial in this patient subset [36]. Although the results of this study support the efficacy of nab-paclitaxel plus carboplatin in patients with SCC, these data should be interpreted with caution, as only $62 \%$ of events had been reported at the time of publication [38].

\section{nab-Paclitaxel in SCC of the head and neck (SCCHN)}

SCCs account for most head and neck cancers [39]. Treatment of SCCHN is complicated and relies on several approaches, including chemotherapy [4]. With this strategy, the preferred treatment regimen for locally advanced (LA) disease is high-dose cisplatin plus concurrent radiotherapy. However, taxane-based regimens are also recommended as induction or sequential chemotherapeutic approaches. Taxanes have also demonstrated activity in the metastatic setting, and paclitaxel and docetaxel (each combined with cisplatin or carboplatin, or as monotherapy) are recommended agents for the treatment of recurrent, unresectable, or metastatic head and neck cancers. Additional treatment options could benefit 
patients with this disease.

nab-Paclitaxel has been investigated in SCCHN, and early clinical evidence supports the feasibility of induction chemotherapy (IC) with nab-paclitaxel. A dose-determining phase I trial recently evaluated the safety and efficacy of combining nab-paclitaxel with cisplatin and fluorouracil as IC followed by chemoradiation (CRT) with carboplatin in previously untreated patients with LA-SCC of the oropharynx [40]. Although median PFS and OS had not been reached at the time of publication, the estimated 1-year PFS rate was $79 \%$ (95\% CI, 0.49-0.93), and the estimated 1-year OS rate was $86 \%$ (95\% CI, 0.49-0.96). Grade $\geq 3$ toxicities included neutropenia, lymphopenia, and hyponatremia. This combination regimen was determined to be feasible for patients with LA-SCCHN and good baseline performance status.

A recent phase II trial further demonstrated promising results with combination nab-paclitaxel IC in LA-SCCHN [41]. Patients $(\mathrm{N}=30)$ received IC with nab-paclitaxel, cetuximab, cisplatin, and 5-fluorouracil followed by concurrent CRT with cisplatin. After 2 cycles of IC, patients who demonstrated a complete response (CR) or partial response (PR) were given an additional cycle of treatment while patients who had stable disease or progressive disease at the primary site received definitive CRT. This combination $n a b$-paclitaxel induction regimen resulted in a CR and PR rate at the primary tumor of $53 \%$ and $47 \%$, respectively. The estimated 2-year OS was $84 \%$ and the estimated 2-year PFS rate was $65 \%$. Grade $\geq 3$ toxicities included fatigue, neutropenia, acneiform rash, and hypokalemia.

nab-Paclitaxel has also been evaluated as part of a CRT regimen following IC with cetuximab and cisplatin for patients with LA-SCCHN [42]. In this phase I dose-determining study (standard 3+3 design), patients $(\mathrm{N}=11)$ received cetuximab followed by CRT with cetuximab, cisplatin, and nab-paclitaxel $25 \mathrm{mg} / \mathrm{m}^{2}$ weekly. Two dose-limiting toxicities occurred in the first 6 patients receiving the regimen with nab-paclitaxel $25 \mathrm{mg} / \mathrm{m}^{2}$, thus the weekly nab-paclitaxel dose was reduced to $20 \mathrm{mg} / \mathrm{m}^{2}$. Of 10 patients, 7 achieved a CR at the primary tumor site after treatment with this regimen. Acute toxicity was manageable, and grade $\geq 3$ lymphopenia was the only reported adverse event to occur in $\geq 10 \%$ of patients. This study demonstrated that weekly nab-paclitaxel $20 \mathrm{mg} / \mathrm{m}^{2}$ is the maximum tolerated dose in this CRT regimen for patients with LA-SCCHN, and a phase II trial is planned.

\section{nab-Paclitaxel in NPC}

Both isolated local recurrences and distant metastases are common in patients with NPC, presenting substantial treatment challenges [4]. The recommended treatment for early-stage disease is radiotherapy with or without platinum-based chemotherapy, as well as IC with a cisplatin-taxane combination regimen. Suggested treatment regimens for metastatic NPC are the same as those for head and neck cancers discussed previously. Identifying new agents for the treatment of this disease could improve outcomes for this patient population.

nab-Paclitaxel has been investigated in the treatment of NPC, yielding encouraging results [28]. In a phase I/II dose-finding study in patients with metastatic NPC, chemonaive patients or patients in whom previous standard treatment had failed were treated with cisplatin $75 \mathrm{mg} / \mathrm{m}^{2}$ every 3 weeks plus 1 of 3 nab-paclitaxel regimens: $n a b$-paclitaxel $260 \mathrm{mg} / \mathrm{m}^{2}$ every 3 weeks $(\mathrm{n}=23), 140 \mathrm{mg} / \mathrm{m}^{2}$ days 1 and 8 every 3 weeks $(\mathrm{n}=22)$, or $100 \mathrm{mg} / \mathrm{m}^{2}$ weekly $(\mathrm{n}=24)$. The ORR was similar between all treatment arms (68\%, $63 \%$, and $65 \%$ for nab-paclitaxel $260 \mathrm{mg} / \mathrm{m}^{2}, 140$ $\mathrm{mg} / \mathrm{m}^{2}$, and $100 \mathrm{mg} / \mathrm{m}^{2}$, respectively; $P=0.94$ ) but significantly higher in chemonaive patients versus those previously treated $(100 \%$ vs. $53 \% ; P<0.01)$. Grade $\geq 3$ toxicities included neutropenia, leukocytopenia, and anemia.

\section{nab-Paclitaxel in esophageal SCC (ESCC)}

Treatment of esophageal cancer relies on a combined modality approach due to the aggressive nature of the disease [3]. For patients with ESCC, recommended treatment of locoregional disease includes surgery, chemotherapy, and CRT. The National Comprehensive Cancer Network guidelines list treatment with carboplatin plus paclitaxel as both a preferred preoperative and definitive CRT regimen [3]. Recommended treatment options for patients with LA unresectable, locally recurrent, or metastatic ESCC include chemotherapy doublets or triplets, including taxane-platinum combinations. In these settings, taxane-based regimens are also listed as preferred options (categories 1, 2A, and 2B) for both first- and second-line treatment. Given the complicated nature of this disease and the resulting treatment challenges, additional effective therapeutic strategies are necessary.

A recent phase II trial evaluating nab-paclitaxel in combination with cisplatin for resectable LA-ESCC yielded positive results [43]. Patients received nab-paclitaxel plus cisplatin followed by esophagectomy. At 4 to 6 weeks after resection, patients received adjuvant treatment with 2 cycles of the combination chemotherapy regimen described. A total of 35 patients were enrolled in the study, with 30 proceeding to surgery. The pathologic complete response rate was $13 \%$, with downstaging observed in more than $60 \%$ of 
patients. All of the patients who proceeded with surgery after neoadjuvant chemotherapy had an R0 resection. Grade $\geq 3$ toxicities included neutropenia, anemia, and thrombocytopenia.

nab-Paclitaxel plus cisplatin could also be a feasible first-line treatment option for metastatic ESCC [44]. In one study, patients who received no prior treatment for metastatic disease $(\mathrm{N}=33)$ were treated with nab-paclitaxel followed by cisplatin. While no CR was observed, 20 patients achieved a PR. The ORR was $61 \%$, and median PFS and OS were 6.2 and 15.5 months, respectively. Treatment was well tolerated, with only 4 patients experiencing grade 3 toxicities. Incidence of grade $\geq 3$ toxicities was low and included leukocytopenia and neutropenia.

\section{nab-Paclitaxel in cancers of the cervix}

SCC accounts for the majority of cervical cancers [45]. Patients who develop metastatic disease have a poor prognosis [46]. Chemotherapy is recommended for patients with metastatic disease who are not candidates for radiotherapy or surgery, and combination paclitaxel and/or platinum-based regimens as well as treatment with single agents (including cisplatin, carboplatin, and paclitaxel) are recommended first-line options [2]. Although cisplatin is considered to be the most effective agent for patients with metastatic disease, platinum-based monotherapy outcomes can be worse in these patients, given the frequent use of this treatment in primary disease. For women who have progressed after first-line treatment and for those who are not candidates for combination chemotherapy, single-agent second-line therapy with several agents including docetaxel is recommended. However, more effective second-line treatment options are needed.

nab-Paclitaxel has demonstrated antitumor activity in this patient population [47]. The Gynecologic Oncology Group evaluated nab-paclitaxel monotherapy in women with metastatic or recurrent SCC or nonsquamous cervical cancer who had progressed or relapsed after prior treatment. In this phase II trial, 35 patients were evaluable for efficacy. The ORR was 29\% (95\% CI, 14.6\%-46.3\%) with PRs lasting a median of 6.0 months (range, 1.5-9.2 months). Another 15 patients $(43 \%)$ had stable disease lasting a median of 5.8 months (range, 3.7-11.4 months). The median PFS and OS were 5 and 9.4 months, respectively. Grade $\geq 3$ toxicities were uncommon, but included anemia, fatigue, and neutropenia.

\section{Summary of the outcomes of $n a b$-paclitaxel in the treatment of cancers with SCC histology}

\section{Efficacy}

The studies discussed in this review demonstrate that nab-paclitaxel is an important treatment option among various solid tumors of SCC histology. nab-Paclitaxel regimens have demonstrated ORRs ranging from $38 \%$ to $74 \%$ and a median OS ranging from 9.7 to 10.7 months [31, 33, 36, 38]. Although results are limited, in patients with SCCHN, including ESCC as well as NPC, nab-paclitaxel regimens have demonstrated encouraging survival results in this population; a median OS of up to 15.5 months has been reported [28, 40-44]. In patients with cervical cancer, which is most often of SCC histology, nab-paclitaxel plus cisplatin has also demonstrated favorable results, with a $29 \%$ ORR and a median OS of 9.4 months [47]. Further studies are warranted to confirm the findings of these early studies; however, early results in these various tumor types with SCC histology indicate the promising activity of nab-paclitaxel.

\section{Safety}

Across all studies of nab-paclitaxel regimens in SCC histology mentioned in this review, the most common grade $\geq 3$ adverse events observed include neutropenia, anemia, thrombocytopenia, and peripheral neuropathy $[28,31,33,34-36,38,40-44,47]$. These events are consistent with those reported in phase III trials of nab-paclitaxel combination regimens in patients with unselected advanced NSCLC and advanced pancreatic cancer and nab-paclitaxel monotherapy in metastatic breast cancer [35, 48, 49]. These adverse events are manageable with dose modifications, and in the case of peripheral neuropathy, several of the phase III studies demonstrated improvement from grade $\geq 3$ to lower grades within $\approx 1$ month in most patients [35, 48, 49]. Overall, the safety profile of nab-paclitaxel-based regimens appears to be consistent across multiple studies.

\section{Conclusions}

nab-Paclitaxel has demonstrated improved tolerability, drug bioavailability, and efficacy compared with its solvent-based counterpart. Currently, nab-paclitaxel is approved for monotherapy treatment of metastatic breast cancer after failure of combination chemotherapy for metastatic disease or relapse within 6 months of adjuvant chemotherapy (prior therapy should have included an anthracycline unless contraindicated), first-line treatment of LA or metastatic NSCLC in combination with carboplatin in patients 
who are not candidates for curative surgery or radiation therapy, and first-line treatment of metastatic pancreatic cancer in combination with gemcitabine [13]. However, several studies provide evidence that supports a potential role for nab-paclitaxel in cancers with SCC histology, including NSCLC, ESCC, SCCHN, NPC, and cervical cancer. Although results are encouraging, further clinical research is necessary to elucidate the role of nab-paclitaxel-based regimens in these and other SCCs.

\section{Acknowledgements}

The authors received editorial support from Dena Jacob, PhD, MediTech Media, funded by Celgene Corporation. The authors were fully responsible for the content and editorial decisions for this report.

\section{Competing Interests}

The authors have declared that no competing interest exists.

\section{References}

[1] Moore DH, Blessing JA, McQuellon RP, Thaler HT, Cella D, Benda J, et al. Phase III study of cisplatin with or without paclitaxel in stage IVB, recurrent, or persistent squamous cell carcinoma of the cervix: a gynecologic oncology group study. J Clin Oncol 2004;22:3113-9.

[2] NCCN Clinical Practice Guidelines in Oncology. Cervical Cancer. V2.2015. http://www.nccn.org/professionals/physician_gls/pdf/cervical.pdf. Accessed April 9, 2015

[3] NCCN Clinical Practice Guidelines in Oncology. Esophageal and Esophagogastric Junction Cancers. http://www.nccn.org/professionals/physician_gls/pdf/esophageal.pdf. Accessed April 9, 2015.

[4] NCCN Clinical Practice Guidelines in Oncology. Head and Neck Cancers. V2.2014.

http://www.nccn.org/professionals/physician_gls/pdf/head-and-neck.pdf. Accessed April 9, 2015

[5] Schiff PB, Fant J, Horwitz SB. Promotion of microtubule assembly in vitro by taxol. Nature 1979;277:665-7.

[6] Schiff PB, Horwitz SB. Taxol stabilizes microtubules in mouse fibroblast cells. Proc Natl Acad Sci U S A 1980;77:1561-5.

[7] Rowinsky EK, Donehower RC. Paclitaxel (taxol). N Engl J Med 1995;332:1004-14.

[8] [No authors listed]. Taxol (paclitaxel) injection [package insert]. Princeton, NJ: Bristol-Myers Squibb Company; 2011.

[9] [No authors listed]. Taxotere (docetaxel) injection concentrate, intravenous infusion (IV) [package insert]. Bridgewater, NJ: sanofi-aventis US, LLC; 2014.

[10] ten Tije AJ, Verweij J, Loos WJ, Sparreboom A. Pharmacological effects of formulation vehicles : implications for cancer chemotherapy. Clin Pharmacokinet 2003;42:665-85.

[11] Gelderblom H, Verweij J, Nooter K, Sparreboom A. Cremophor EL: the drawbacks and advantages of vehicle selection for drug formulation. Eur J Cancer 2001;37:1590-8

[12] Weiss RB, Donehower RC, Wiernik PH, Ohnuma T, Gralla RJ, Trump DL, et al. Hypersensitivity reactions from taxol. J Clin Oncol 1990;8:1263-8.

[13] [No authors listed]. Abraxane for injectable suspension (paclitaxel protein-bound particles for injectable suspension) (albumin-bound) [package insert]. Summit, NJ: Celgene Corporation; 2014.

[14] Desai N, Trieu V, Yao Z, Louie L, Ci S, Yang A, et al. Increased antitumor activity, intratumor paclitaxel concentrations, and endothelial cell transport of cremophor-free, albumin-bound paclitaxel, ABI-007, compared with cremophor-based paclitaxel. Clin Cancer Res 2006;12:1317-24.

[15] Chen N, Li Y, Ye Y, Palmisano M, Chopra R, Zhou S. Pharmacokinetics and pharmacodynamics of nab-paclitaxel in patients with solid tumors: disposition kinetics and pharmacology distinct from solvent-based paclitaxel. J Clin Pharmacol 2014:54:1097-107.

[16] John TA, Vogel SM, Tiruppathi C, Malik AB, Minshall RD. Quantitative analysis of albumin uptake and transport in the rat microvessel endothelial monolayer. Am J Physiol Lung Cell Mol Physiol 2003;284:L187-96.
[17] Schnitzer JE, Oh P. Albondin-mediated capillary permeability to albumin. Differential role of receptors in endothelial transcytosis and endocytosis of native and modified albumins. J Biol Chem 1994;269:6072-82.

[18] Matsumura Y, Maeda H. A new concept for macromolecular therapeutics in cancer chemotherapy: mechanism of tumoritropic accumulation of proteins and the antitumor agent smancs. Cancer Res 1986;46:6387-92.

[19] Cetin K, Ettinger DS, Hei YJ, O'Malley CD. Survival by histologic subtype in stage IV nonsmall cell lung cancer based on data from the Surveillance, Epidemiology and End Results Program. Clin Epidemiol 2011;3:139-48.

[20] NCCN Clinical Practice Guidelines in Oncology. Non-Small Cell Lung Cancer. V5.2015. http://www.nccn.org/professionals/physician_gls/pdf/nscl.pdf. Accessed April 9, 2015

[21] [No authors listed]. Avastin (bevacizumab) solution for intravenous infusion. South San Francisco, CA: Genentech, Inc; 2014.

[22] [No authors listed]. Alimta (pemetrexed for injection), for intravenous use. Indianapolis, IN: Eli Lilly and Company; 2013.

[23] Desai N, Trieu V, Damascelli B, Soon-Shiong P. SPARC expression correlates with tumor response to albumin-bound paclitaxel in head and neck cancer patients. Transl Oncol 2009;2:59-64.

[24] Yardley DA. nab-Paclitaxel mechanisms of action and delivery. J Control Release 2013;170:365-72.

[25] Chin D, Boyle GM, Williams RM, Ferguson K, Pandeya N, Pedley J, et al. Novel markers for poor prognosis in head and neck cancer. Int J Cancer 2005;113:789-97.

[26] Koukourakis MI, Giatromanolaki A, Brekken RA, Sivridis E, Gatter KC, Harris $\mathrm{AL}$, et al. Enhanced expression of SPARC/osteonectin in the tumor-associated stroma of non-small cell lung cancer is correlated with markers of hypoxia/acidity and with poor prognosis of patients. Cancer Res 2003;63:5376-80

[27] Watkins G, Douglas-Jones A, Bryce R, Mansel RE, Jiang WG. Increased levels of SPARC (osteonectin) in human breast cancer tissues and its association with clinical outcomes. Prostaglandins Leukot Essent Fatty Acids 2005;72:267-72.

[28] Zhang L, Liang W, Huang Y, Zhao LP, Zhao HY, Wu X, et al. A dose-finding study of nanoparticle albumin-bound paclitaxel plus cisplatin in patients with metastatic nasopharyngeal carcinomas. J Clin Oncol 2014;32(5 suppl): abstract6049.

[29] Infante JR, Matsubayashi H, Sato N, Tonascia J, Klein AP, Riall TA, et al. Peritumoral fibroblast SPARC expression and patient outcome with resectable pancreatic adenocarcinoma. J Clin Oncol 2007;25:319-25.

[30] Liang W, Zhao L, Wu X, Huang Y, Zhao H, Li Z. Biomarker analyses of a phase I/II study of nanoparticle albumin-bound paclitaxel plus cisplatin in the treatment of advanced nasopharyngeal carcinomas. Ann Oncol 2014;25(suppl 4):iv58-84.

[31] Bertino EM, Williams TM, Shilo K, Villalona-Calero MA, Phillips GS, Mo X, et al. Phase 2 trial of nab-paclitaxel plus carboplatin for advanced NSCLC in patients at risk of bleeding from VEGF directed therapies. Int J Radiat Oncol Biol Phys 2014;90:S45.

[32] Hidalgo M, Plaza C, Illei P, Brachmann C, Heise C, Pierce D, et al. SPARC analysis in the phase III MPACT trial of nab-paclitaxel (nab-P) plus gemcitabine $(\mathrm{Gem})$ vs Gem alone for patients with metastatic pancreatic cancer (PC). Ann Oncol 2014;25 (suppl 2):ii106.

[33] Fang Y, Wang L, Xia GH, Shi MQ. Clinical investigation of efficacy of albumin bound paclitaxel plus platinum compounds as first-line chemotherapy for stage III/IV squamous non-small cell lung cancer. Asian Pac J Cancer Prev 2014;15:7453-7.

[34] Green MR, Manikhas GM, Orlov S, Afanasyev B, Makhson AM, Bhar P, et al. Abraxane, a novel Cremophor-free, albumin-bound particle form of paclitaxel for the treatment of advanced non-small-cell lung cancer. Ann Oncol 2006:17:1263-8.

[35] Socinski MA, Bondarenko I, Karaseva NA, Makhson AM, Vynnychenko I, Okamoto I, et al. Weekly nab-paclitaxel in combination with carboplatin versus solvent-based paclitaxel plus carboplatin as first-line therapy in patients with advanced non-small-cell lung cancer: final results of a phase III trial. J Clin Oncol 2012;30:2055-62.

[36] Socinski MA, Okamoto I, Hon JK, Hirsh V, Dakhil SR, Page RD, et al. Safety and efficacy analysis by histology of weekly nab-paclitaxel in combination with carboplatin as first-line therapy in patients with advanced non-small-cell lung cancer. Ann Oncol 2013;24:2390-6.

[37] Socinski MA, Spigel DR, Ko A, Renschler MF. Oral presentation at: IASLC 15th World Conference on Lung Cancer; October 27-31, 2013; Sydney, Australia [abstract 3438].

[38] Yang JJ, Huang C, Song Y, Cheng Y, Chen GY, Yan HH, et al. A phase II trial of first-line nab-paclitaxel/carboplatin versus gemcitabine/carboplatin in advanced squamous cell carcinoma of the lung (CTONG1002). Ann Oncol 2014;25(suppl 4):iv426-70.

[39] SEER training modules. Introduction to head \& neck cancer. http://training.seer.cancer.gov/head-neck/intro/. Accessed April 9, 2015.

[40] Loong HH, Winquist E, Waldron J, Chen EX, Kim J, Palma D, et al. Phase 1 study of nab-paclitaxel, cisplatin and 5-fluorouracil as induction chemotherapy followed by concurrent chemoradiotherapy in locoregionally advanced squamous cell carcinoma of the oropharynx. Eur J Cancer 2014;50:2263-70.

[41] Adkins D, Ley J, Trinkaus K, Thorstad W, Lewis J Jr, Wildes T, et al. A phase 2 trial of induction nab-paclitaxel and cetuximab given with cisplatin and 5 -fluorouracil followed by concurrent cisplatin and radiation for locally 
advanced squamous cell carcinoma of the head and neck. Cancer 2013;119:766-73.

[42] Nedzi LA, Sumer B, Myers L, Truelson J, Hughes R, Young G, et al. Phase 1 study of nab-paclitaxel, cisplatin and cetuximab with concurrent radiation therapy for local-regionally advanced head-and-neck squamous cell carcinoma (HNSCC). Presented at: American Society for Radiation Oncology (ASTRO) 52nd Annual Meeting; October 31-November 4, 2010; San Diego, CA [poster 2530].

[43] Fan Y, Zhou X, Jiang Y, Chen Q, Huang Z, Gong L, et al. A phase II study of weekly nab-paclitaxel in combination with cisplatin as neoadjuvant chemotherapy in patients (pts) with locally advanced esophageal squamous cell carcinoma (SCC). J Clin Oncol 2014;32(suppl 3):abstract122.

[44] Shi Y, Qin R, Wang ZK, Dai GH. Nanoparticle albumin-bound paclitaxel combined with cisplatin as the first-line treatment for metastatic esophageal squamous cell carcinoma. Onco Targets Ther 2013;6:585-91.

[45] American Cancer Society. What is cervical cancer? http://www.cancer.org/ cancer/cervicalcancer/detailedguide/cervical-cancer-what-is-cervical-cancer. Accessed April 9, 2015.

[46] SEER Stat Fact Sheets: Cervix Uteri Cancer. http://seer.cancer.gov/statfacts/html/cervix.html. Accessed April 9, 2015

[47] Alberts DS, Blessing JA, Landrum LM, Warshal DP, Martin LP, Rose SL, et al. Phase II trial of nab-paclitaxel in the treatment of recurrent or persistent advanced cervix cancer: a gynecologic oncology group study. Gynecol Oncol 2012;127:451-5.

[48] Gradishar WJ, Tjulandin S, Davidson N, Shaw H, Desai N, Bhar P, et al. Phase III trial of nanoparticle albumin-bound paclitaxel compared with polyethylated castor oil-based paclitaxel in women with breast cancer. J Clin Oncol 2005;23:7794-803.

[49] Von Hoff DD, Ervin T, Arena FP, Chiorean EG, Infante J, Moore M, et al. Increased survival in pancreatic cancer with nab-paclitaxel plus gemcitabine. New Engl J Med 2013;369:1691-703. 